\title{
THE MAGNA CARTA AND THE CONTEMPORARY RULE OF LAW PROBLEM
}

\author{
R. George Wright*
}

\section{INTRODUCTION}

With the octocentenary ${ }^{1}$ of the Magna Carta, ${ }^{2}$ attention has been drawn to due process of law, ${ }^{3}$ to the law of the land, ${ }^{4}$ and to the nature and value of the rule of law. ${ }^{5}$ The Magna Carta famously promises in particular that

\footnotetext{
* Lawrence A. Jegen Professor of Law, Indiana University Robert H. McKinney School of Law.

${ }^{1}$ See Octocentenary, OXFORD English DictionARY (3d ed. 2004); see also Octocentennial, OXFORD ENGLISH DiCTIONARY (3d ed. 2004).

${ }^{2}$ For access to texts, translations, commentaries, and citations, see, for example, Magna Carta, THE BRITISH LiBRARY, www.bl.uk/magna-carta (last visited Sept. 18, 2015); U.S. NATIONAL ARCHIVES AND RECORDS ADMINISTRATION, The Magna Carta, FEATURED Documents, http://www.archives.gov/exhibits/featured_documents/magna_carta/ (last visited Sept. 18, 2015), and ThE MAgNA CARTA PROJECT, http://magnacartaresearch.org (last visited Sept. 18, 2015).

${ }^{3}$ Professor Jerry Mashaw has argued that "[t]he term 'due process of law'-which meant procedure by original writ or by an indicting jury-first appears in place of 'the law of the land' in the 1354 statutory interpretation of Magna Charta by Parliament, under Edward III.” JERRY L. MASHAW, Due Process in the Administrative State 50 n.1 (1985) (citing J.C. Holt, Magna Carta 9 (1965)); see also id. at 50; Hannis Taylor, Due Process of Law, 24 YALE L.J. 353, 354 (1915) ("The English idea of due process was first embodied in chapter [or clause] 39 of the Magna Carta ....”). For a classic linkage of chapter 39 and the idea of due process, see JOSEPH STORY, COMMENTARIES ON THE Constitution of the United States § 932, at 663 (Ronald D. Rotunda \& John E. Nowak rev. ed., 1987) (1833).

${ }^{4}$ For discussions of the Magna Carta's reference to "the law of the land," see, for example, DAVID CARPenter, Magna CARTa 52, 53 (ed. \& trans., Penguin Books 2015); DANNy DanZiger \& JOHN Gillingham, 1215: The Year of Magna CARTa 273 (2005); Magna CARTA AND the Rule of LAW 40 (Daniel Barstow Magraw et al., eds., 2015); Nicholas Vincent, MAGNA CARTA: The Foundation OF Freedom 1215-2015 (2015)); and C.H. McIlwain, Due Process of Law in Magna Carta, 14 Colum. L. REV. 27, 51 (1914) (seeking to define "the law of the land" in the context of the Magna Carta). The ideas of due process of law and of adhering to the law of the land are often taken to be more or less equivalent. See, e.g., Murray v. Hoboken Land \& Improvement Co., 59 U.S. 272, 276 (1855) (equating "due process of law" and the "law of the land," in at least some senses and contexts); Edward J. Eberle, Procedural Due Process: The Original Understanding, 4 CONST. COMMENT. 339, 341 (1987) ("Sir Edward Coke identified 'the law of the land' with 'due process of law' . . ..”); Isaac Franklin Russell, Due Process of Law, 14 YALE L.J. 322, 326 (1905) ("In Murray, . . Justice Curtis says: 'The words 'due process of law' were undoubtedly intended to convey the same meaning as the words 'by the law of the land' in Magna Charta. Lord Coke, in his commentary on those words says they mean due process of law."'). For Coke's language, see EdwARdo CoKE, THE SECOND PART OF THE INSTITUTES OF THE LAWS OF ENGLAND 50 (The Lawbook Exch., Ltd., 2002) (1642). For a more nuanced view of this purported equation, see Edward S. Corwin, The Doctrine of Due Process of Law Before the Civil War, 24 HARV. L. REV. 366, 369 (1911).

${ }^{5}$ For brief references to the idea of the rule of law in the context of the Magna Carta, see, for example, CARPENTER, supra note 4, at vii-viii (noting that the rule of law is the "fundamental principle"
} 
"[n]o free man shall be seized ${ }^{6}$ or imprisoned ... except by the lawful judgment of his equals ${ }^{7}$ or by the law of the land."

If we think about the rule of law as thus gestured at by the Magna Carta, we may find that the precise nature of the rule of law is more contested than the general positive value of the rule of law. As one leading scholar has put it, "[e]veryone, it seems, is for the rule of law." This Article will suggest, however, that even a unanimous and sincere collective endorsement of the rule of law would not ensure the rule of law's continued vitality.

The logic of this conclusion requires, first, an introduction to mainstream understandings of the rule of law, ${ }^{10}$ and to some assumed benefits of the rule of law. ${ }^{11}$ This Article then briefly explores several closely related contexts in which important rule of law concerns arise. ${ }^{12}$ The institution of the rule of law is then diagnosed, at least by analogy, as what is called an undersupplied public good, ${ }^{13}$ with attention then being devoted especially to standard problems of an improperly regulated "commons" $" 14$ and to some elements of modern game theory, ${ }^{15}$ including the possible strategic payoffs to a legal actor of apparent "madness" 16 in rule of law contexts.

In pursuit of a constructive response to the chronic, systematic

asserted by the Magna Carta). See also David Carpenter, Magna Carta -800 Years On, THE GUARDIAN (Jan. 2, 2015, 9:00 AM), http://www.theguardian.com/books/2015/jan/02/magna-carta800th-anniversary-relevance-david-carpenter (noting the Magna Carta's "appeal lay not in its precise details, but in its assertion of the rule of law"). For a roughly parallel near-contemporary treatment, see Thomas Aquinas, Summa TheOlOGicA, at pt. I, question 96, art. 5, reply to objection 3 (Fathers of the English Dominican Province trans. rev. 2d ed., 1920), www.newadvent.org/summa/index.html; A.E. Dick Howard, Magna CARTA: TeXt And Commentary 14 (rev. ed., 1998) (referring to the Magna Carta's clause 39 and to the idea of the law of the land as of "enormous significance in the development of" the idea of "the rule of law, a government of laws and not of men").

${ }^{6}$ Timeliness: Sources from History: Magna Carta 1215, THE BRITISH LIBRARY, http://www.bl.uk/learning/timeline/item95692.html (last visited Sept. 15, 2015). For the alternative translation as "arrested," see DANZIGER \& GILLINGHAM, supra note 4, at 273.

7 Timeliness: Sources from History, supra note 6. For the alternative translation as "peers," see DANZIGER \& GILLINGHAM, supra note 4, at 273.

${ }^{8}$ CARPENTER, supra note 4, at 53 (translating what is now numbered as clause 39).

9 Brian Z. Tamanaha, The History and Elements of the Rule of Law, 2012 Sing. J. LEGAL STUD. 232, 232 (2012). See also Republican Party of Minnesota v. White, 536 U.S. 765, 795 (2002) (Kennedy, J., concurring); id. at 804 (Ginsburg, J., dissenting); Antonin Scalia, The Rule of Law as a Law of Rules, 56 U. CHI. L. REV. 1175, 1176 (1989).

${ }^{10}$ See infra Part II.

11 See infra Parts II \& IV.

12 See infra Part III (Jeopardizing the rule of law is plainly not confined to any particular governmental branch, level, party, or ideology.).

${ }^{13}$ See infra Part IV.

${ }^{14}$ See infra Part IV.

15 See infra Part IV.

${ }^{16}$ See infra Part IV. 
undersupply of the rule of law, this Article then explores the idea of faithfulness, or fidelity, ${ }^{17}$ and calls attention to some of the basic virtues of character most distinctively relevant to sustaining the rule of law. ${ }^{18}$ The hope is that cultivating some of the most relevant virtues of character can change not only the otherwise collectively undesirable of choice "payoffs" available to public officials who inadvertently undermine the rule of law, but the capacities and underlying values and priorities that public officials bring to such choices.

\section{SOME UNDERSTANDING OF THE RULE OF LAW AND ITS ECONOMIC VALUE}

For purposes of this Article, we need not settle upon any particular conception of the rule of law. But we do need some sense of the mainstream understandings, in order to test the relevance of the claims made below. We can start with the minimalist, or merely narrow, understanding provided by Professor Brian Tamanaha. Professor Tamanaha suggests, at the outset, that "[t]he rule of law means that government officials and citizens are bound by and abide by the law." 19

From such beginnings, many contemporary writers have sought to develop multi-part understandings of the rule of law. Among the most prominent of such understandings has been that of Professor Lon Fuller. ${ }^{20}$ Fuller's rule of law criteria are, as it happens, formulated in negative terms, as eight ways of failing to make genuine law:

The first ... lies in a failure to achieve rules at all, so that every issue must be decided ... ad hoc .... The other [ways] are: (2) a failure to publicize, or at least make available to the affected party, the rules he is expected to observe; (3) the abuse of retroactive legislation, which not only cannot itself guide action, but undercuts the integrity of rules prospective in effect, since it puts them under the threat of retrospective change; (4) a failure to make rules understandable; (5) the enactment of contradictory

\footnotetext{
${ }^{17}$ See infra Part V.

18 See infra Part V.

19 Tamanaha, supra note 9, at 233. For an only modestly variant, but similarly concise formulation, consider Frank Knight's claim that "[i]n the liberal view, the individuals who implement state action do not act as individuals, but are the agents of the law, and the law is the creation of the society as a whole, of the 'sovereign people,' and not of individuals." FrANK H. KNIGHT, FREEDOM AND REFORM 75 (LibertyPress 1982) (1947). One could presumably expand Knight's approach to encompass actors who are driven by class or ideological considerations in conflict with the rule of law.

${ }^{20}$ See LON L. Fuller, The Morality OF LAw 33-38 (rev. ed., 1969); see also N.E. Simmonds, Law as a Moral Idea, 55 U. TORONTO L.J. 61, 67 n.10 (2005) (discussing Fuller's criteria as “an adequate (albeit provisional) account of the archetype of law").
} 
rules or (6) rules that require conduct beyond the powers of the affected party; (7) introducing such frequent changes in the rules that the subject cannot orient his action by them; and, finally, (8) a failure of congruence between the rules announced and their actual administration. ${ }^{21}$

A slightly divergent analysis of the rule of law has been offered by Professor John Finnis. ${ }^{22}$ On Finnis's account, the rule of law is a matter of degree, ${ }^{23}$ and exists to the extent that

(i) its rules are prospective, not retroactive, and (ii) are not in any other way impossible to comply with; that (iii) its rules are promulgated, (iv) clear, and (v) coherent one with another; that (vi) its rules are sufficiently stable to allow people to be guided by their knowledge of the rules; that (vii) the making of decrees and orders applicable to relatively limited situations is guided by rules that are promulgated, clear, stable, and relatively general; and that (viii) those people who have authority to make, administer, and apply the rules . . . (a) are accountable for their compliance with rules applicable to their performance and (b) do actually administer the law consistently and in accordance with its tenor. ${ }^{24}$

Finally, the leading contemporary legal theorist Joseph Raz suggests that the rule of law comprises prospectivity, openness, and clarity; ${ }^{25}$ relative stability of the laws; ${ }^{26}$ deriving particular orders through "open, stable, clear, and general rules;" 27 judicial independence; 28 "natural justice" 29 in the sense of open and fair hearings for the sake of "the correct application of

${ }^{21}$ FULLER, supra note 20, at 39.

22 See John Finnis, NATURAL Law And NATURAL Rights 270-72 (2d ed., 2011).

${ }^{23}$ See id. at 270.

${ }^{24}$ Id. at 270-71. Contrast the somewhat more "substantively" oriented multi-part analysis, emphasizing both fundamental human rights and compliance with international law, presented in Lord Bingham, The Rule of Law, 66 CAMBRIDGE L.J. 67-82 (2007).

${ }^{25}$ Joseph Raz, The Rule of Law and Its Virtue, in LiBERTY AND THE RULE OF LAW 3, 7 (Robert L. Cunningham, ed., 1979).

${ }^{26}$ Id. at $7-8$.

${ }^{27}$ Id. at 8 . The genuine openness, predictability, and "compliability" of the law may work against broad and arbitrarily enforced "overcriminalization." See generally Go DIRECTLY TO JAIL: THE CRiminalization OF Almost Everything (Gene Healy, ed., 2004); Jonathan Turley, The Criminalization of America, (Aug. 18, 2007), http://jonathanturley.org/2007/08/18/the-criminalizationof-america/; Ilya Somin, Are There Limits to Executive Discretion in Enforcing Federal Law?, WASH. POST: VOLOKH CONSPIRACY (Nov. 22, 2014), https://www.washingtonpost.com/news/volokhconspiracy/wp/2014/11/22/are-there-limits-to-executive-discretion-in-enforcing-federal-law/ (noting the overcriminalization phenomenon and discussing several broad limits to enforcement discretion).

${ }^{28}$ See Raz, supra note 25, at 10.

${ }^{29}$ Id. 
the law;" ${ }^{30}$ broad but in other respects limited judicial review; ${ }^{31}$ genuine and realistic accessibility of the courts $;^{32}$ and limits on police and prosecutorial discretion. ${ }^{33}$

Among mainstream contemporary accounts of the rule of law, there are important differences as to the role, if any, of explicit substantive human rights $^{34}$ and democratic ${ }^{35}$ considerations. To the extent that promoting fundamental human rights and democratic institutions and values contributes to the rule of law, any possible conflicts between those considerations and other, more formal or procedural, elements of the rule of law may count as tensions that are internal to the rule of law. ${ }^{36}$

${ }^{30} I d$. The rule of law element of fair adjudicative processes is easily linked with procedural due process and with non-arbitrariness. See, e.g., T.M. Scanlon, Due Process, in DuE Process: Nomos XVIII 93, 93-94 (J. Roland Pennock \& John W. Chapman, eds., 1977); Henry J. Friendly, "Some Kind of Hearing," 123 U. PA. L. REV. 1267, 1279-93 (1975) (listing elements of a fair adjudicatory hearing).

31 See Raz, supra note 25, at 10.

${ }^{32}$ See id. at $10-11$.

${ }^{33}$ See id. at 11. See also Ronald A. CASs, The Rule of LAW IN AmeriCA 4-5 (2001) (emphasizing, among other considerations, "fidelity to rules" and "principled predictability"); JOHN RAWLS, A THEORY OF JUSTICE $§ 38$, at 235-43 (1971) (discussing a mainstream understanding of the rule of law, incorporating administrative "justice as regularity," as protecting basic rights and fundamental Rawlsian liberties).

34 See, e.g., FINNIS, supra note 22, at 270-71; Lord Bingham, supra note 24.

35 See, e.g., JÜrgen HABERmas, BetweEn FACTS AND Norms: CONTRIBUtions to a Discourse THEORY OF LAW AND DEMOCRACY 449 (William Rehg, trans., 1996) ("[T]here is a conceptual or internal relation, and not simply a historically contingent association, between the rule of law and democracy.").

${ }^{36}$ Imagine, for example, a situation in which promoting democracy is possible only through the unpredictable and arbitrary exercise of broad administrative discretion. In some such cases, the exercise of broad administrative discretion may thus promote democracy in some respects, while also tending to impair democracy in other respects. Resolving such unavoidable conflicts may require the exercise of the virtues of sound prudential judgment and practical wisdom. See C.D.C. REEVE, ARISTOTLE ON PRACTICAL Wisdom: NicomacheAn ETHics bk. VI ch. 5 (trans., 2013).

More concretely, consider the possible conflict between adherence to constitutionalized law making procedures under the separation of powers and persistent "gridlock" at the federal level. For divergent perspectives on (chronic) gridlock, see, for example, Michael J. Gerhardt, Why Gridlock Matters, 88 NOTRE DAME L. REV. 2107, 2108-2111 (2013) (discussing the costs and benefits of the various sorts of gridlock); R. Shep Melnick, The Conventional Misdiagnosis: Why "Gridlock" Is Not Our Central Problem and Constitutional Revision Is Not the Solution, 94 B.U. L. REV. 767, 768-69 (2014) (focusing not on gridlock, but on unresolved conflicts among our highest priorities and most popular programs); and Michael J. Teter, Congressional Gridlock's Threat to Separation of Powers, 2013 WIS. L. REV. 1097 (congressional gridlock as inviting ad hocery, gimmicks, and a vacuum-filling expansion of executive initiatives).

More concretely yet, consider the rule of law issues implied by Justice Alito's concerns:

the aggrandizement of the power of administrative agencies as a result of . . (1) the effective delegation to agencies by Congress of huge swaths of lawmaking authority, (2) the exploitation by agencies of the uncertain boundary between legislative and interpretive rules, and (3) this Court's cases holding that courts must ordinarily defer to an agency's 
For our purposes, it is unrealistic to analyze practical rule of law problems by simultaneously applying perhaps a dozen or so partly conflicting, partly overlapping, and partly mutually supportive considerations. Nor, however, can the idea of the rule of law be uncontroversially reduced to a single phrase. Therefore, rule of law theory cannot be uncontroversially applied like a template. Realistically, we will assume that any intuitively relevant legal phenomenon, whether deemed desirable or undesirable, can be linked to one or more of the specific rule of law elements cited above. ${ }^{37}$

The rule of law, however it may be reasonably defined, of course has many attractions. ${ }^{38}$ Often overlooked, or underemphasized in many valuations of the rule of law, however, is a linkage between the rule of law and worthwhile societal economic development. Insofar as the rule of law, as genuinely embodied in practice, limits official arbitrariness, ${ }^{39}$ unpredictability, ${ }^{40}$ and various sorts of uncertainties, ${ }^{41}$ it can promote fair and sustainable economic growth and development.

Thus, it has been concluded that the rule of law in practice is "important for growth." ${ }^{2}$ A bit more elaborately, the scholars Daron Acemoglu and James A. Robinson have concluded that "inclusive" 43 economic and political institutions both support, and are supported by, an established legal order. $^{44}$ More flatly, Niall Ferguson argues that "[f]ew truths are today more universally acknowledged than that the rule of law ... is conducive to economic growth." 45 Or, on a more specific formulation, "[i]f there is no means of ensuring that an agreement is enforced, then the ability to establish productive relationships is severely curtailed." ${ }^{, 46}$

interpretation of its own ambiguous regulations.

Perez v. Mortg. Bankers Ass'n, 135 S. Ct. 1191, 1210 (2015) (Alito, J., concurring in part and concurring in the judgment).

${ }^{37}$ See supra notes 19-35 and accompanying text.

${ }^{38}$ See supra notes 25-33 and accompanying text.

39 See supra notes $21,24,26-27$ and accompanying text.

40 See supra notes $21,24,26-27$ and accompanying text.

${ }^{41}$ See supra notes 21, 24, 26-27 and accompanying text. For some economically inhibiting effects of "uncertainty" in a somewhat technical sense, see FRANK H. KNIGHT, RISK, UNCERTAINTY, AND Profit pt. III, at 237-38 (John McClure ed., Singalman Publishing 2009) (1921), https://mises.org/library/risk-uncertainty-and-profit.

42 Elhanen Helpman, The Mystery of ECONOMiC Growth 141 (2004).

43 Daron acemoglu \& James A. Robinson, Why Nations Fail: The Origins of Power, PROSPERITY, AND POVERTY 430 (2012).

${ }^{44}$ Id. at 429-30.

${ }^{45}$ Niall Ferguson, The Great Degeneration: How Institutions Decay and ECONOMies Die 84 (2013).

${ }^{46}$ John Kay, Culture And Prosperity 13 (2005). See also William J. Baumol et AL., Good 
It may well be that economic growth and development in general are linked to at least some elements of the rule of law. But this is not to claim that the rule of law, however defined, guarantees balanced, sustainable, non-exploitive, fair and equitable long-term economic growth. Potentially, some applications of the rule of law might even undermine economic growth. ${ }^{47}$ Nor should we assume that the globally largest economies will all score well, internationally, on all rule-of-law and related values; ${ }^{48}$ apparently, at this point, there is evidence that the United States does not. ${ }^{49}$

Even if we give the rule of law little credit for economic growth, the value of the rule of law in various other respects, including the protection of elemental personal dignity from official contempt, remains. ${ }^{50} \mathrm{We}$ shall, in any event, sensibly assume hereafter that the rule of law, in one or more senses traceable at least as far back as the Magna Carta, ${ }^{51}$ is of genuine value.

Threats to, and conflicts within, ${ }^{52}$ the rule of law can similarly take many forms. ${ }^{53}$ Immediately below, we address some closely related

CAPITALISM, BAD CAPITALISM, AND THE ECONOMICS OF GROWTH AND PROSPERITY 154-55 (2007); David S. Landes, The Wealth And Poverty of Nations: Why Some ARE So Rich and Some So POOR 217-18 (1998).

${ }^{47}$ Economically damaging discrimination against particular groups that was once sporadic, informal, and unpredictable could later be written into the law, and systematically, uniformly enforced to the letter. Such a development would tend to undermine broad economic growth, while admittedly in some respects at least minimally promoting some rule of law values. On the other hand, invidious discrimination may certainly undermine at least some substantive rights-oriented understandings of the rule of law, if not largely proceduralist understandings as well. The Supreme Court, it should be noted, wrote in Bolling v. Sharpe that "discrimination may be so unjustifiable as to be violative of due process." 347 U.S. 497, 499 (1954). For serious explorations of the nature and value of due process, see supra notes 3, 4, and 30.

${ }^{48}$ See Ferguson, supra note 45, at 100-01.

${ }^{49}$ See id. (citing Global Competitiveness Report, THE WORLD ECONOMIC FORUM, www.weforum.org/reports/global-competitiveness (last visited Sept. 18, 2015)).

${ }^{50}$ See, e.g., supra notes 3, 4, 9, and 24; Peter H. SCHUCK, Why GOVERnMENT FaILS So Often AND HOW IT CAN DO BETTER 299 (2014) (listing "legitimacy, accuracy, dignity, consistency, predictability, transparency, and democratic accountability" as general values and benefits associated with the rule of law); Brian Z. TAMANAHA, ON THE RULE OF LAW: History, POLITICS, THEORY chs. 7-11 (2004); Jeremy Waldron, The Rule of LAW AND the MEASURE OF Property 76-77 (2012) (The rule of law is less a relentless defender of private property rights than as a potential force for public, including environmental, goods); see also RAWLS, supra note 33 (discussing the role of the rule of law in the broader Rawlsian scheme of justice as fairness). For a classic discussion of various benefits of the rule of law, and the costs of arbitrary measures and procedures, see Benjamin Constant, Principles of Politics Applicable to All Representative Governments, in POLITICAL Writings 169, 28995 (Biancamaria Fontana ed. \& trans., 1988) (1815).

${ }^{51}$ See supra note 5.

${ }^{52}$ Most fundamentally, there may well be cases in which allowing a private actor a meaningful hearing, see Friendly, supra note 30, at 1275-80, will tend to reduce the certainty or predictability of the legal outcomes, see KNIGHT, supra note 41.

${ }^{53}$ For a recent assertion that one general sort of separation of powers context is thus problematic, see the interesting developments pointed to by Justice Alito in Perez v. Mortgage Bankers Ass' $n$. $135 \mathrm{~S}$. 
contexts in which structural and institutional problems for the rule of law have arisen. Some sense of the threats to the rule of law should assist in eventually seeing the rule of law as a systematically undersupplied collective good, and as vulnerable to particular unfortunate strategies adopted by key government officials.

\section{SOME ASPECTS OF THE RULE OF LAW PROBLEM OF DISCRETIONARY NON-ENFORCEMENT}

For the sake of sheer manageability in depicting threats to the rule of law, let us begin simply with the provocative appellate opinion of Judge Brett Kavanaugh in the nuclear waste disposal case of In re Aiken County. ${ }^{54}$ The Aiken case involved the Nuclear Regulatory Commission, an independent federal agency. ${ }^{55}$ The case focus was on the alleged ongoing agency refusal, past a statutory deadline, to approve or disapprove, through a partially funded review process, the Department of Energy's application to dispose of radioactive waste at Nevada's Yucca Mountain storage facility. ${ }^{56}$ A prior appellate opinion had noted the likely appropriateness of a writ of mandamus in the event of continued agency noncompliance with the statutory hearing requirements. ${ }^{57}$

Judge Kavanaugh sought to summarize, in broad terms, the crucial underlying constitutional and rule of law principles at issue:

[T] he President must follow statutory mandates so long as there is appropriated money available and the President has no constitutional objection to the statute. So, too, the President must abide by statutory prohibitions unless the President has a constitutional objection to the prohibition. If the President has a constitutional objection to a statutory mandate or prohibition, the President may decline to follow the law unless and until a final Court order dictates otherwise. But the President

Ct. 1199, 1210 (2015) (Alito, J., concurring in part and concurring in the judgment) (noting "(1) the effective delegation to agencies by Congress of huge swaths of law-making authority, (2) the exploitation by agencies of the uncertain boundary between legislative and interpretive rules, and (3) this Court's cases holding that courts must ordinarily defer to an agency's interpretation of its own ambiguous regulations").

54725 F.3d 255 (D.C. Cir. 2013). See Recent Case, D.C. Circuit Compels Nuclear Regulatory Commission to Follow Statutory Mandate - In re Aiken County, 725 F.3d 255 (D.C. Cir. 2013), 127 HARV. L. REV. 1033, 1035-36 (2014) (interpreting Judge Kavanaugh as concluding that "while the President has significant prosecutorial discretion to decline to enforce a statute against a private party, the Executive cannot disregard a statutory mandate on the executive branch itself') (footnotes omitted).

${ }^{55}$ In re Aiken County, 725 F.3d at 257.

56 See id. at 257-59.

${ }^{57}$ See In re Aiken County, 645 F.3d 428, 436 (D.C. Cir. 2011). The more recent Aiken County opinion noted the same. In re Aiken County, 725 F.3d at 258. 
may not decline to follow a statutory mandate or prohibition simply because of policy objections. ${ }^{58}$

At the same time, Judge Kavanaugh emphasized the breadth of presidential discretion in other important contexts. Thus, Presidents may exercise "a significant degree of prosecutorial discretion not to take enforcement actions against violators of a federal law."59 More broadly, " $[\mathrm{t}]$ he President may decline to prosecute or may pardon because of the President's own constitutional concerns about a law or because of policy objections to the law, among other reasons." 60 Thus, in general, "Congress may not mandate that the President prosecute a certain kind of offense or offender." ${ }^{61}$ A President's declining, to some extent, to prosecute privateparty violations of law may, Judge Kavanaugh argued, thereby "protect individual liberty." $" 62$

The Aiken County case did not, however, involve any sort of prosecutorial discretion on Judge Kavanaugh's analysis. ${ }^{63}$ Judge Kavanaugh concluded that "[p]rosecutorial discretion does not include the power to disregard other statutory obligations . . . such as statutory requirement to issue rules, ${ }^{64}$. . to pay benefits, or to implement or

${ }^{58}$ In re Aiken County, 725 F.3d at 259 (emphasis omitted). In support for the proscription of presidential non-compliance on mere policy grounds, Judge Kavanaugh cited Lincoln v. Vigil, 508 U.S. 182, 193 (1993). See In re Aiken County, 725 F.3d at 260. Presumably, objecting to one statutory provision on grounds of its conflict with another statute would fall somewhere between a constitutional objection and a mere policy objection.

${ }^{59}$ In re Aiken County, 725 F.3d at 262.

${ }^{60} \mathrm{Id}$. at 263 (emphasis in the original) (citing, inter alia, United States v. Nixon, 418 U.S. 683, 693 (1974))

${ }^{61}$ Id a 263 (emphasis omitted) (relying on AKHIL REED AMAR, AMERICA's CONSTITUTION: A BIOGRAPHY 179 (2005) (The "greater power to pardon subsumed the lesser power to simply decline prosecution.")). The problem with some greater-power-includes-the-lesser-power arguments is that the supposed lesser-included power does not fall entirely within the scope of the supposedly moreencompassing "greater" power. That is, the lesser-included power raises concerns foreign to those raised by the "greater" power. See e.g., 44 Liquormart, Inc. v. Rhode Island, 517 U.S. 484, 510-511 (1996) (disavowing the claim that the power to prohibit casino gambling entirely encompasses the supposedly lesser included power to prohibit the advertising of such an activity); Posadas de P.R. Assocs. v. Tourism Co. of P.R., 478 U.S. 326, 345-46 (1986)) (also stating that "the greater power to completely ban casino gambling necessarily includes the lesser power to ban advertising of casino gambling"). It is also not clear that the power to pardon, exonerate, forgive, or rehabilitate encompasses the power to prosecute, to call into official suspicion, or to officially stigmatize a person.

${ }^{62}$ In re Aiken County, 725 F.3d at 264. In some contexts, de-emphasizing prosecution of crimes with discrete and recognizable victims may re-distribute important liberties toward perpetrators and away from victims.

63 See id. at 266.

${ }^{64}$ Id. (citing Massachusetts v. EPA, 549 U.S. 497, 527-28 (2007)). 
administer statutory projects or programs. ${ }^{.65}$ To oversimplify, there is permissible discretion and there is impermissible disregarding.

The crucial problem with this attempted distinction by Judge Kavanaugh is that prosecutorial-or more broadly, executive or administrative - discretion is essentially implicated in even the statutorily mandated ${ }^{66}$ responsibility "to implement or administer statutory projects or programs." ${ }^{67}$ There is, according to Judge Kavanaugh, the exercise of discretion on one side of the dichotomy, and the administration of statutory programs on the other. But no such crisp dichotomy is realistic. Undoubtedly, there are many cases that can indeed be placed on one side or the other of this dichotomy. Whether to appeal a judgment adverse to the United States is largely a matter of discretion. ${ }^{6}{ }^{\text {In contrast, to provide a }}$ prospective Justice of the Peace with a formal commission may, in contrast, fall within the proper scope of a writ of mandamus. ${ }^{69}$ But the existence of easy cases on both sides of a supposed discretionary/non-discretionary dichotomy does not tell us much about how to address less easy cases as they inevitably arise.

For our purposes, it is useful to recognize that even under the general rule of law, no court decision, no set of articulable rules, and no determinate principles of any sort can tell the courts or the public in general whether any reasonably debatable case falls inside or outside the legitimate discretion of the otherwise authorized governmental decision-maker. Ultimately, even the precise extent to which Congress, the President, or lower courts should be guided by the letter and spirit of Supreme Court decisions is subject to contest, and not optimally decided by appeal merely to some set of articulable rules or principles. As we shall see, ${ }^{70}$ something else is realistically needed as well.

Nor does there seem to be any obvious way to reformulate Judge Kavanaugh's discretion versus no discretion dichotomy to enhance its usefulness. Judge Kavanaugh himself offered the following alternative statement: "[P]rosecutorial discretion encompasses the discretion not to enforce a law against private parties; it does not encompass the discretion not to follow a law imposing a mandate or prohibition on the Executive Branch." ${ }^{, 71}$ On this version of Judge Kavanaugh's dichotomy, we can again

\footnotetext{
${ }^{65} \mathrm{Id}$.

${ }^{66}$ And, we may assume, constitutionally unquestioned.

${ }^{67}$ In re Aiken County, 725 F.3d at 266.

${ }^{68}$ See, e.g., United States v. Mendoza, 464 U.S. 154, 161-62 (1984).

${ }^{69}$ See Marbury v. Madison, 5 U.S. (1 Cranch) 137, 139 (1803).

${ }^{70}$ See infra Part V.

${ }^{71}$ In re Aiken County, 725 F.3d at 266 (emphasis in original).
} 
see some vague, general distinction between the realm of the discretionary and the realm of the mandatory, or between enforcement discretion and not transgressing statutory requirements. But again, no articulable holding, rule, principle, or set thereof can by itself adequately address the range of reasonable contestable cases. ${ }^{72}$

As for the scope of administrative discretion, what the rule of law permits is again not reducible to any rule, or even to a looser articulable principle or principles of any sort. We know that at one extreme, administrative actors commonly have some appropriate discretion, given the separation of powers, to decline to enforce a valid rule. ${ }^{73}$ But at the other extreme, an agency's broad refusal to enforce any rules in any context would plainly violate our intuitive sense of the rule of law and of the constitutional separation of powers.

Judicial cases are decided, even at their broadest, on constitutional or positive international law grounds, rather than on explicit and pure rule of law grounds. ${ }^{74}$ But if it is difficult to confidently set the proper bounds for permissible administrative non-enforcement of rules even at statutory or constitutional levels, it should not surprise us that broad rule of law considerations do not dictate limits to such non-enforcement practices with any precision.

Consider both the good sense, and the tentativeness and uncertainty, manifested in the Court's treatment of the leading case of Heckler $v$. Chaney. ${ }^{75}$ Chaney involved an attempt by death row prisoners to judicially require the FDA to enforce one of its safety and efficacy rules in the unique context of lethal drug injections. ${ }^{76}$ The Court decided this case largely on the basis of a presumption against judicial review of an agency's discretionary refusal to enforce such a rule, particularly in light of limited agency resources and competing enforcement priorities. ${ }^{77}$

\footnotetext{
72 Consider in this context the Court's admission that "the line between measures that remedy or prevent unconstitutional actions and measures that make a substantive change in the governing law is not easy to discern." City of Boerne v. Flores, 521 U.S. 507, 519-20 (1997), superseded by statute, Religious Land Use and Institutionalized Persons Act (RLUIPA), Pub. L. No. 106-274, 114 Stat. 803 (codified at 42 U.S.C. $§ 2000 \mathrm{cc}$ et seq.), as recognized in Burwell v. Hobby Lobby Stores, Inc., 134 S. Ct. 2751 (2014). Courts have also attempted to sort out the substantive-versus-procedural rule dichotomy. Air Transp. Ass'n of Am. v. Dep't of Transp., 900 F.2d 369, 375-78 (D.C. Cir. 1990), vacated as moot, 933 F.2d 1043 (D.C. Cir. 1991); Am. Hosp. Ass'n v. Bowen, 834 F.2d 1037 (D.C. Cir. 1987).

73 See Heckler v. Chaney, 470 U.S. 821, 837-38 (1985).

74 This is not to deny the fundamental overlaps between, say, constitutional rights to minimal due process, and one or more elements of the rule of law. See supra notes 3-9 and accompanying text.

75470 U.S. 821.

76 See id. at 823.

${ }^{77}$ See id. at 832-33.
} 
At the same time, the Chaney Court, or at least one or more of its members in dicta, recognized some of the difficulties in justifying a broad endorsement of agency discretion in declining to enforce rules. ${ }^{78}$ Thus, the Court recognized that the presumption against judicial review in such cases is, in turn, a narrow exception to a broader presumption in favor of judicial review of final agency action. ${ }^{79}$ The Court in Chaney also explicitly set apart an otherwise similar hypothetical case in which the enforcement plaintiffs raised constitutional rights issues. ${ }^{80}$

Justice Brennan's concurring opinion raised in dicta other possible limits on an agency's decision not to enforce a presumably valid rule, some with a distinct rule of law flavor. ${ }^{81}$ Thus, Justice Brennan referred not only to nonenforcement in a possible violation of constitutional rights, but to cases involving: an agency's incorrect belief that it lacks the relevant statutory jurisdiction; a "pattern of [agency] nonenforcement of clear statutory language;" and an agency's presumably absolute refusal to enforce a concededly valid statute. ${ }^{82}$

But Justice Brennan did not intend to have exhausted the major complications. In language suggestive of one of the Magna Carta's most rule of law-oriented provisions ${ }^{83}$ Justice Brennan further argued that "[i]t is possible to imagine other nonenforcement decisions ${ }^{84}$ made for entirely illegitimate reasons, for example, nonenforcement in return for a bribe," in which the presumption of nonreviewability would be rebutted. ${ }^{85}$

${ }^{78}$ See id. at 839 (Brennan, J., concurring); id. at 854-55 (Marshall, J., concurring in the judgment).

${ }^{79}$ See id. at 837-38 (majority opinion).

${ }^{80}$ See id. at 838 .

${ }^{81}$ See id. at 838 (Brennan, J., concurring).

${ }^{82}$ Id. at 839.

${ }^{83}$ See Magna Carta, THE BRITISH LIBRARY, cl. 40, http://www.bl.uk/magna-carta/articles/magnacarta-english-translation (last visited Sept. 18, 2015) ("To no one will we sell, to no one deny or delay right or justice.").

${ }^{84}$ Justice Brennan's logic at this point would seem to encompass the corrupt minimization or nonenforcement of apparently valid administrative judicial cases and agency rules, or statutes.

${ }^{85}$ Chaney, 470 U.S. at 839 (Brennan, J., concurring). For further discussion of Chaney and other instances of discretionary agency non-action, see, for example, Massachusetts v. EPA, 549 U.S. 497, 527-28 (2007) ("Refusals to promulgate rules are thus susceptible to judicial review, though such review is 'extremely limited' and 'highly deferential"') (quoting Nat'l Customs Brokers \& Forwarders Ass'n of Am., Inc. v. United States, 883 F.2d 93, 96 (D.C. Cir. 1989)). See also Nat. Res. Def. Council, Inc. v. FDA, 760 F.3d 151, 170-71 (2d Cir. 2014) (citing Chaney); Conservancy of Sw. Fla. v. U.S. Fish \& Wildlife Serv., 677 F.3d 1073, 1084-85 (11th Cir. 2012) (discussing both Chaney and Massachusetts v. EPA); Sierra Club v. Jackson, 648 F.3d 848, 855-56 (D.C. Cir. 2011) (discussing Chaney at length); Tamenut v. Mukasey, 521 F.3d 1000, 1003-04 (8th Cir. 2008) (en banc) (per curium) (discussing both Chaney and the Lincoln v. Vigil, 508 U.S. 182 (1993), presumption of judicial reviewability of agency action); Lisa Schultz Bressman, Judicial Review of Agency Inaction: An Arbitrariness Approach, 79 N.Y.U. L. REV. 1657, 1667-69 (2004) (discussing Chaney); Cass R. Sunstein, Reviewing Agency Inaction After Heckler v. Chaney, 52 U. CHI. L. REV. 653, 655 (1985) (linking the statutory presumption 
In this context, as elsewhere, administrative discretion is both commonly desirable and realistically inevitable. ${ }^{86}$ But as one commentator has observed, administrative discretion "can threaten the most precious rule of law values-legitimacy, accuracy, dignity, consistency, predictability, transparency, and democratic accountability ${ }^{87}$-if it is too broad or uncontrolled." 88 It is possible for either the positive or the negative exercise of discretion, cumulatively or in the aggregate, to perhaps inadvertently threaten the rule of law. A key problem in addressing such threats, however, is that there again seems to be no articulable formula, rule, or principle of any sort, or any set thereof, that would reliably protect the rule of law from such more or less inadvertent threats. ${ }^{89}$ Let us clarify the nature of the problem. Immediately below, we describe an important category of typically unintended but chronic threats to the rule of law.

\section{THE RULE OF LAW AS AN UNDERSUPPLIED PUBLIC GOOD}

On any reasonable definition, ${ }^{90}$ even an imperfect rule of law system will commonly be thought of as what is called a "public good." In saying this, we do not mean merely that the general rule of law is widely, or even universally, valued. As a public good, the rule of law is more or less systematically "underproduced" because those who might at some personal cost contribute to, strengthen, or enhance the rule of law realistically cannot appropriate more than a fraction of the value of doing so, ${ }^{91}$ or derive

of judicial review to the value of fidelity to statutory requirements, as well as to the broader rule of law).

${ }^{86}$ See, e.g., Kenneth Culp Davis, Discretionary Justice: A Preliminary InQuiry (1969); H.L.A. Hart, Discretion, 127 HARV. L. REV. 652 (2013).

${ }^{87}$ We do not suggest that these values, or the risks thereto, arise only at the level of the broad rule of law, and not also at the level of interpreting a specific statutory or constitutional provision.

${ }^{88}$ SCHUCK, supra note 50. For the briefest selection of recent commentary, see, for example, Kate Andrias, The President's Enforcement Power, 88 N.Y.U. L. Rev. 1031, 1112 (2013) ("The President is not constitutionally invested with either legislative power or the power to suspend or dispense with the law. But it is hard to distinguish between these practices and legitimate exercises of enforcement power."); Eugene Gressman, Take Care, Mr. President, 64 N.C. L. Rev. 381, 384 (1986) ("[T]he Executive can refuse to defend the constitutionality of a statute . . . But this is a far cry from . . . ignoring or refusing to execute it in the first instance."); Jeffrey A. Love \& Arpit K. Garg, Presidential Inaction and the Separation of Powers, 112 MICH. L. REV. 1195, 1201 (2014) ("[W]hen the president intentionally abandons his duty to enforce the laws passed by Congress, he is unilaterally making policy for the whole nation ...."); Zachary S. Price, Enforcement Discretion and Executive Duty, 67 VAND. L. REV. 671, 674 (2014) ("[A]uthority for enforcement discretion exists-but it is both limited and defeasible.").

${ }^{89}$ See infra Part V.

${ }^{90}$ See supra Part II.

91 See, e.g., Tyler Cowen, Public Goods, in The CONCISE ENCYClOPEDIA OF ECONOMICS, (David R. Henderson ed., 2d ed. 2008), www.econlib.org/library/Enc/PublicGoods.html (last visited Aug. 11, 2015). See also Charles E. LindBlom, The Market System: What It Is, How It Works, AND WhAT TO MAKE OF IT 147 (2001) ("Perhaps the most telling market inefficiency is that, although 
meaningful compensation or reward in any other form. We thus may well wind up with less rule of law than we all may prefer, and, in some sense, would be collectively willing to pay for.

While few goods are always and everywhere public goods in this sense, and while being a public good is often a matter of degree, we can think of national defense or a police system, an ambient atmosphere cleansed of pollutants, and even a large-scale fireworks show as public goods. ${ }^{92} \mathrm{~A}$ good qualifies, by definition, as "public" in this sense roughly because it is not feasible to prevent nonpaying individuals from enjoying the good along with those who do pay, thus creating an incentive for everyone to seek "to ride free" or avoid making their own payment. ${ }^{93}$ And secondarily, unlike in the case of, say, an apple pie, no person's consumption of the good reduces the amount of the good available for consumption by others. ${ }^{94}$ These two qualities are what make a good a "public good."

The rule of law, as an institution, typically fits within this understanding of a public good. ${ }^{95}$ Consider an analogy: rather like the way in which an individual act of littering may contribute, however marginally, to the public bad of visual pollution, so a particular official decision may contribute, perhaps without anyone's intention, expectation, or even recognition, to an overall erosion of the rule of law. The cumulative erosion of the rule of law arising from such official actions, or inactions, can at least in a loose sense be thought of as akin to what is called a negative externality. ${ }^{96}$ In such a case, the private costs of some official decision, as judged by the actor and by those most immediately affected, may well fail to incorporate or to internalize to those actors, the broader public costs, including any incremental erosion of the rule of law. ${ }^{97}$

Thus, we might say that the institution of the rule of law is a valuable

efficiency requires that all benefits and costs be weighed regardless of where they fall, market participants weigh only their own" or those of persons and groups with which they identify.).

92 See Cowen, supra note 91.

${ }^{93}$ See id. For the germ of the idea of a public good, see DAVID HuME, A TREATISE OF HuMAN NAture 534-539 (L.A. Selby-Bigge \& P.H. Nidditch eds., Oxford Univ. Press 2d ed. 1978) (1738-40).

${ }^{94}$ See Cowen, supra note 91.

${ }_{95}$ Where it seems more convenient, we can equally think of acts or omissions tending to undermine the rule of law as producing, or as in themselves, "public bads," as we might similarly think of a toxic atmosphere as a public bad.

96 See Thomas C. Schelling, Micromotives And Macrobehavior 213 n.13 (1978) (referring to externalities as effects of, say, a person's actions that are outside the scope of that actor's accounting of their interests or concerns, but within the accounting of, or affecting the interests of non-consenting parties).

${ }^{97}$ See, e.g., Paul M. Johnson, Externality, in A GlosSARY OF Political ECONOMY TERMS (2005) www.auburn.edu/ johnspm/gloss/externality (last visited Aug. 12, 2015); Bryan Caplan, Externalities, in The Concise Encyclopedia of Economics (David R. Henderson ed., 2d ed. 2008), www.econlib.org/library/Enc/Externalities.html (last visited Aug. 12, 2015). 
but imperfectly conserved resource subject, at least by analogy, to the problems associated with typical public goods. In thinking of the rule of law as at least akin to a public good, our attention should thus be on divergence between the private, internalized costs of legal or policy decisions and the greater costs imposed thereby on a much broader public over time through an incremental erosion of the rule of law. ${ }^{98}$

Certainly, the rule of law may be dramatically under-produced, or under-maintained, when official decision making is driven by narrow, selfish motives, such as unpunished bribery or other personal corruption. ${ }^{99}$ The official in such an extreme case personally absorbs only a very small fraction of the distinctively rule-of-law costs he imposes on society. But the rule of law may actually be more severely damaged by official decision making, in violation of the rule of law, with broad, abstract, and altruistic motives, as to advance an ideological cause. Neither narrow nor broad motives for official choices that undermine the rule of law should necessarily be thought of as "irrational." 100 The constitutional checks and balances seeking to control the effects of potentially tyrannical ambition should realistically be aimed at least as much at broad or theory-driven motives as at narrow, selfish motives. ${ }^{101}$

An initial practical problem is that not all public bads are equally obvious. Crucially, the "public bads" associated with incrementally undermining the rule of law are unlikely to be readily or widely visible. In other contexts, public bads are clearly evident to any observer. Overgrazed common land or dense atmospheric soot can be rationalized or dismissed, but not denied. The gradual undermining of the rule of law, on the other hand, may well be far less conspicuous. ${ }^{102}$ Worse, incremental, adverse effects on the rule of law may not even be more or less rigorously provable. ${ }^{103}$ Cases in which an official must realistically argue that the

\footnotetext{
${ }^{98}$ See Bressman, supra note 85, at 1660-61 (distinguishing between "narrow interests" and "public purposes" in the context of agency inaction).

99 See supra note 85 and accompanying text.

${ }^{100}$ See Bressman, supra note 85, at 1660 .

101 Simone Weil, On the Abolition of All Political Parties 12 (Simon Leys trans., 2013) (1957) (noticing the tendency for even the most obviously partisan or group-focused political ideologies to envision themselves as promoting the broad public interest). See also THE FEDERALIST No. 51 (James Madison) (describing how government must first govern its citizens but also govern itself).

${ }^{102}$ See Shelley E. Taylor, The Availability Bias in Social Perception and Interaction, in JudGMENT UNDER UNCERTAINTY: HeURISTICS AND BiASES 190, 190-200 (Daniel Kahneman, et al., eds., 1982).

${ }^{103}$ Whether one can visually see any particular concentration of atmospheric mercury or not, at least the presence of mercury in the atmosphere is clearly demonstrable. See Michigan v. EPA, $135 \mathrm{~S}$. Ct. 2699 (2015). More broadly, consider the problems of "causal density" discussed in Jim Manzi, What Social Science Does-and Doesn't-Know, City Journal, Summer 2010, at 13, www.cityjournal.org/2010/20_3.
} 
benefits of some decision outweigh its admittedly adverse effects on the rule of law will thus be unfortunately rare.

But there is a further practical problem: clean air and the rule of law are presumably both public goods. This does not mean, however, that clean air and the rule of law would both count as what we might call ideally preferred options among their respective alternatives. We might ideally prefer a rule in which we, and only we, are allowed to avoid our selfincurred cleaning costs by polluting the air. Clean air, however we define it, ${ }^{104}$ is all we normally ${ }^{105}$ aspire to, in terms of air quality. The idea of selfishly preferring something distinctly different, atmospherically, from clean air in general - as opposed to dirty air - may not have much meaning. Clean air does not typically prompt us to seek for better air.

In contrast, though, many of us would be inclined, out of self-interest, to rank the rule of law as substantially inferior to other imaginable alternatives. Many competent decision-makers could self-interestedly think of any rule of law system as distinctly second-best, if that. One such alternative would be a system under which the particular decision-maker, or the decision-maker's group, is arbitrarily favored by the law in one or more respects. Some might prefer a unique immunity from civil or criminal penalties to a genuine rule of law system. ${ }^{106}$ Some might prefer to exercise official authority far beyond that authorized by rule-of-law systems, ${ }^{107}$ whether shortsightedly or rationally, given their values and priorities. All of this suggests that even within the broad category of often undersupplied ${ }^{108}$ public goods, the rule of law may be particularly vulnerable to

${ }^{104}$ See Whitman v. Am. Trucking Ass'n, 531 U.S. 457, 465 (2001) (discussing the regulatory complications associated with air quality).

${ }^{105}$ But see Cinnabon Classic Cinnamon Roll Scented Oil, AIR Wick, http://www.airwick.us/products/plug-ins-scented-oils/cinnabon-classic-cinnamon-roll-scented-oil/ (last visited Aug. 19, 2015); Oxygen Bars: Is a Breath of Fresh Air Worth It?, MedicineNet.com, www.medicinenet.com/script/main/art.asp?articlekey=21800 (last updated Nov. 19, 2002).

${ }^{106}$ We could, for example, interpret the questioning of Socrates by Glaucon and Adeimantus in the Republic as addressing the wisdom and prudence of being broadly exempt from institutional justice and the rule of law. Cf. Plato, The Republic 44-56 (Robin Waterfield trans., Oxford Univ. Press, 1993) ( 370 BCE).

${ }^{107}$ See, e.g., THE Federalist No. 51, supra note 101. More colorfully, consider the various possibilities depicted in Suetonius, Lives of THE CAESARS 165, 202-03 (Catharine Edwards trans., Oxford Univ. Press 2000) (121 A.D.) (describing Caligula as threatening to appoint his horse as consul and Neronian disdain for the rule of law).

${ }^{108}$ See supra note 91 and accompanying text. So-called common pool, or common resource, cases do not involve genuine public goods, but certainly pose problems of (literal) erosion or eventual undersupply of a valuable resource. Professor Elinor Ostrom inventoried a number of possible solutions to common-pool problems beyond either exhaustive property rights or external coercion, and which avoid both over-utilization of common resources and excessive administrative and monitoring costs. See Elinor OSTROM, GOVERning THE COMMONS: THE EVOLUTION OF INSTITUTIONS FOR COLLECTIVE 
de-prioritizing and erosion.

Some of the threats to the rule of law that are the most difficult to address are really not unique to the rule-of-law context. Consider, for example, what we might call the problem of rational strategic irresponsibility in public decision making. In particular, imagine an elected official or body, or at least credibly appears to be, willing to risk substantial costs, borne by everyone alike in terms of the institutional rule of law. Those substantial rule-of-law costs may-and perhaps clearly will-be incurred by all unless some significant political or legal concession is made to the person or group credibly threatening the rule of law. In such a case, assuming official irresponsibility, it may be of little use to claim that the party threatening the rule of law might lose more by undermining the rule of law than it would gain by extracting the political or legal concession at issue. Thus, the broad problem of rational strategic irresponsibility.

This problem of rational strategic irresponsibility has been popularized in other contexts, most notably by the game theorist Thomas Schelling. ${ }^{109}$ The most basic elements of the problem have long been appreciated. ${ }^{110}$ If one fervently wants a political or legal outcome - along with the largely unimpaired rule of law - one's best strategy may be to credibly pretend to be indifferent to any risks that may inevitably be involved in the pursuit of one's goals.

Thus, Professor Schelling has observed that "[i]t is a paradox of deterrence that in threatening to hurt somebody if he misbehaves, it need not make a critical difference how much it would hurt you too-if you can make him believe the threat. People walk against traffic lights on busy

ACTION (1990). Professor Ostrom recognizes the "tragedy of the commons" problems that were popularized by Professor Garrett Hardin. See Garrett Hardin, The Tragedy of the Commons, 162 SCIENCE 1243, 1245 (1968) ("The rational man finds that his share of the cost of the wastes he discharges into the commons is less than the cost of purifying his wastes before releasing them."); Garrett Hardin, Extensions of "The Tragedy of the Commons," 280 SCIENCE 682 (1998). Many scholars anticipated Hardin's argument. See W. F. Lloyd, On the Checks to Population (1832), 6 PopULATION \& DEV. REV. 473, 483 (1980) (noting incentives to overgraze common land at the level of individuals); Aristotle, The Politics 44 (Ernest Barker trans., Oxford Univ. Press 2d ed. 1958) ( 335-22 BCE) ("What is common to the greatest number gets the least amount of care. Men pay most attention to what is their own: they care less for what is common; or at any rate, they care for it only to the extent to which each is individually concerned.").

109 See Thomas C. Schelling, The Strategy of Conflict 16-18 (rev. ed. 1980); Thomas C. SCHELLING, ARMS AND INFLUENCE 36-37, 91 (2008 ed.); see also, e.g., Larry Alexander \& Emily Sherwin, The Deceptive Nature of Rules, 142 U. PA. L. REV. 1191, 1195 n.9 (1994) ("If one wants to be a rational deterrer of others' threatening acts, one may have to become irrational.”); Jeffrey Kimball, Did Thomas C. Schelling Invent the Madman Theory?, HistORY News NeTwORK (Oct. 24, 2005), http://historynewsnetwork.org/article/17183.

110 See Niccolo Machiavelli, The Discourses, in The Prince And The Discourses 403, 403404 (Luigi Ricci trans., E.R.P. Vincent rev., 1950) ("It may at times be the highest wisdom to simulate folly."); see also id. at 404 ("It is advisable then at times to feign folly."). 
streets, deterring trucks by walking in front of them."111

So a cultivated, but credible, indifference toward the risks one proposes to run with regard to immensely valuable goods, such as the rule of law, ${ }^{112}$ may pay off with concessions in the form of political or legal gains, along with a temporarily unimpaired, or only slowly impaired, rule of law.

This unfortunate possibility presents problems in both rule of law and other contexts. Such strategies clearly put the rule of law and its values at risk. The strategy of risking even fundamental damage to the rule of law is available to all major legal actors. Such a strategy may be adopted, perhaps simultaneously, in various rule of law contexts by multiple opposing actors. In such cases, even universally disfavored outcomes involving serious damage to the rule of law can arise as a result of miscalculation, misdirected emotion, out-of-control emotion, or an insufficiently comprehensive approach to reasonable choice. ${ }^{113}$

The risk of rule of law outcomes that no one desires may be quite substantial, as the literature on game theory's Prisoner's Dilemma ${ }^{114}$ suggests. It is, however, also possible to imagine that legal and political machinations among opposing public actors could be conducted with only modest risk to rule of law values. ${ }^{115}$ Overtime, we are not collectively powerless when faced with public good-type threats to the rule of law. Reducing the risks to rule of law values would influence not only the structure of legal institutions ${ }^{116}$ and the broader culture, ${ }^{117}$ but also, as

111 SCHELLING, ARMS AND INFLUENCE, supra note 109, at 36 (emphasis in original).

112 Or a world habitat unimpaired by a nuclear winter, in the nuclear arms context.

113 See Robert Frank, Passions Within Reason: The Strategic Role of the Emotions (1988) (discussing the potentially useful role of cultivated, or uncultivated but genuine, emotion in avoiding unattractive outcomes).

${ }^{114}$ For the possible divergence in general between the public interest and personal interests, see Bressman, supra note 85, at 1712-13 \& n.280. For game theory background, see, for example, Steven Kuhn, Prisoner's Dilemma, Stan. EnCyClopedia Phil. (rev. Aug. 29, 2014), http://plato.stanford.edu/entries/prisoner-dilemma (describing a wide variety of prisoner's dilemma-type games). The basic idea of a prisoner's dilemma situation, as often arises in law and politics, is that the most rational choice for each player individually may turn out, when conjoined with the choices of other individual players, to lead to a worse outcome for all players than could, in theory, have been achieved. See id.

115 See, e.g., Robert AXElrod, The COMPleXity of COOPERATION: AgENT-BASED Models of COMPETITION AND COLLABORATION 4-6 (1997) (discussing the successes in some contexts of the socalled tit-for-tat strategies).

116 See THE FEDERALIST No. 51, supra note 101 ("In framing a government which is to be administered by men over men, the greatest difficulty lies in this: you must first enable the government to control the governed; and in the next place oblige it to control itself. A dependence on the people is, no doubt, the primary control on the government; but experience has taught mankind the necessity of auxiliary precautions.”).

${ }^{117}$ See Shirli Kopelman, The Effect of Culture and Power of Cooperation in Common Dilemmas: Implications for Global Resources Management (Ross Sch. of Bus., Working Paper No. 1072, 2008), 
argued below, would crucially influence virtues of character, temperament, and judgment. ${ }^{118}$

\section{THE PROBLEM OF FAITHFULNESS TO LAW AND THE ROLE OF RELEVANT VIRTUES}

Let us consider federal government actors insofar as they are constitutionally bound by a duty of "faithfulness." Beyond the presidential oath of office ${ }^{119}$ and the more widely applied oath of constitutional fidelity, ${ }^{120}$ the Constitution imposes a distinctive rule of law-related burden on the President. The President is textually required to execute the laws. ${ }^{121}$ But that execution of the laws must meet more than some minimalist standard of what constitutes bare "execution" of the laws; rather, that execution must be done "faithfully."122 The textual idea of "faithful execution" is not to be lightly judged as a rhetorical flourish, or a mere redundancy. ${ }^{123}$ The idea, instead, has the potential to be constructive. Faithfulness, or fidelity, to law is of course not confined to the President. Most conspicuously, the courts ${ }^{124}$ and the broader executive branch $^{125}$ in executing their respective duties are among the actors similarly bound by the idea of fidelity to the rule of law.

The meaning of "faithfulness" in rule of law contexts is, unfortunately, not free from confusion. ${ }^{126}$ In the constitutional context in particular, the idea of fidelity has been said to encompass the ideas of, respectively, "following the rules laid down;", 27 seeking to give legal effect to original

\footnotetext{
http://papers.ssrn.com/sol3/papers.cfm?abstract_id=305005 (discussing possible cultural and historical differences in our overall responses to prisoner's dilemma circumstances).

118 See infra Part V.

119 See U.S. CONST. art. II, § 1, cl. 8.

${ }^{120}$ See id. art. VI, cl. 3.

121 See id. art. II, § 3.

${ }^{122} \mathrm{Id}$.

${ }^{123}$ See David Luban, "That the Laws Be Faithfully Executed:" The Perils of the Government Legal Advisor, 38 OHIO N.U. L. REV. 1043, 1050 (2012) (“That word 'faithfully' is there to do some work."); see also Somin, supra note 27.

124 "Judges should not have political constituencies. Rather, a judge's fidelity must be to enforcement of the rule of law regardless of perceived popular will.” Republican Party of Minnesota v. White, 536 U.S. 765, 803 (2002) (Stevens, J., dissenting) (internal quotations omitted).

${ }^{125}$ See, e.g., Sunstein, supra note 85 (noting that judicial review of administrative agency actions generally promotes the rule of law and agency "fidelity to statutory requirements").

126 See Steven J. Burton, Breach of Contract and the Common Law Duty to Perform in Good Faith, 94 HARV. L. REV. 369, 372 n.17 (1980) (noting the term "good faith" appears in many different legal contexts and that the "[f]ailure to keep different contexts analytically distinct can result in much confusion").

${ }^{127}$ Symposium, Editors' Forward, Fidelity in Constitutional Theory, 65 FordHAM L. REV. 1247, 1247 (1997) (citing Justice Antonin Scalia). But see Mark V. Tushnet, Following the Rules Laid Down:
} 
understandings ${ }^{128}$ fidelity to the constitutional founders' broader vision; ${ }^{129}$ synthesizing distinct constitutional periods and revolutionary changes; $;{ }^{130}$ translation to contemporary contexts; ${ }^{131}$ and the pursuit of constitutional integrity through a justifying morality and interpretive fit. ${ }^{132}$

All of these approaches to the meaning of constitutional fidelity have their own uses. But since they collectively encompass a range of the mainstream approaches to broad constitutional interpretation in general, it is not clear whether the idea of faithfulness in this context is really doing much work. Does a "faithful" interpretation of the Constitution on the above approaches mean anything more specific than whatever one takes to be the overall best general interpretation of the Constitution? Simply put, in the constitutional context, is the idea of a "faithful" interpretation distinctively narrower and more focused than the general idea of a "proper" or "well-justified" interpretation?

Perhaps at least slightly more illuminating of the broad idea of faithfulness in carrying out the law is the private law of contractual performance. Bad faith, or lack of faithfulness, in performing one's private contractual obligations has been said to involve, for example, "evasion of the spirit of the deal, lack of diligence and slacking off, willful rendering of only substantial performance, abuse of a power to specify terms, abuse of a power to determine compliance, and interference with or failure to cooperate in the other party's performance." ${ }^{\prime 13}$ Each of these admittedly still broad phenomena, taken from the law of private contract performance, at least adds some concreteness to the inquiry into government actor faithfulness, beyond that contributed by the various contesting theories of constitutional fidelity above. ${ }^{134}$

In the end, though, our ability to more or less detect and deter without controversy, or punish lack of faithfulness to the rule of law, will inevitably

A Critique of Interpretivism and Neutral Principles, 96 HARV. L. REV. 781, 785 (1983) (noting that interpretivism's assumption that "the meanings of words and rules are stable over extended periods" is incompatible with liberalism's "individualist premise").

${ }^{128}$ Fidelity in Constitutional Theory, supra note 127 (citing Judge Robert Bork).

129 See id. (citing Professor Jack Rakove).

${ }^{130}$ See id. (citing Professor Bruce Ackerman).

131 See id. (citing Professor Lawrence Lessig); see also Lawrence Lessig, Fidelity in Translation, 71 TEX. L. REV. 1165, 1171-73 (1993) (arguing that interpretive fidelity should be examined through concepts of linguistic translation and fidelity to the original text).

${ }^{132}$ See Fidelity in Constitutional Theory, supra note 127 (citing Professor Ronald Dworkin); see also Ronald Dworkin, The Moral Reading of the Constitution, N.Y. REV. BoOKS (Mar. 21, 1996), http://www.nybooks.com/articles/archives/1996/mar/21/the-moral-reading-of-the-constitution/.

${ }^{133}$ Robert S. Summers, "Good Faith" in General Contract Law and the Sales Provisions of the Uniform Commercial Code, 54 VA. L. REV. 195, 232-33 (1968).

${ }^{134}$ See supra notes $127-32$ and accompanying text. 
be insufficient. ${ }^{135}$ This is true especially given the nature of the rule of law as an undersupplied public good. ${ }^{136}$ Impeachment, ${ }^{137}$ congressional budgeting and oversight, ${ }^{138}$ and censure, ${ }^{139}$ for example, are blunt and often unadjustable instruments, utilized at best after the fact, and rarely threatened, let alone actually imposed, in many important rule of law cases. Incremental but cumulatively substantial damage to the rule of law can occur before any institutional, structural, formal, or separation of powersrelated mechanisms are deployed. ${ }^{140}$ The alternative approach of institutionally subsidizing the production of the rule of law by rewarding rule of law-sustaining behavior also raises almost unimaginable practical difficulties. ${ }^{141}$

Especially given the undersupplied public good and the game theoretic considerations referred to above, ${ }^{142}$ it should not surprise us that institutional mechanisms are not by themselves realistically sufficient to optimally sustain and promote the rule of law. In another, somewhat different, context Judge Learned Hand similarly reported that:

I often wonder whether we do not rest our hopes too much upon constitutions, upon laws and upon courts. These are false hopes; believe me, these are false hopes. Liberty lies in the hearts of men and women; when it dies there, no constitution, no law, no court can save it; no constitution, no law, no court can even do much to help it. ${ }^{143}$

135 See supra Part IV.

136 See supra Part IV.

137 See U.S. CONST. art. II, § 4.

138 See, e.g., Clinton v. City of New York, 524 U.S. 417, 449 (1998) (holding presidential line-item veto unconstitutional); U.S. Term Limits, Inc. v. Thornton, 514 U.S. 779, 780 (1995) (holding stateimposed limits on congressional tenure unconstitutional); INS v. Chadha, 462 U.S. 919, 920 (1983) (holding legislative veto mechanisms unconstitutional). Note also the chronic problem of departures from any classically contemplated process of congressional budgeting.

${ }^{139}$ See U.S. CONST. art. 1, § 5, cl. 2; see also Expulsion and Censure, United STATES SENATE, http://www.senate.gov/artandhistory/history/common/briefing/Expulsion_Censure.htm (last visited Sept. $25,2015)$ (discussing Senate expulsion and censure cases).

${ }^{140}$ See THE FEDERALIST No. 51, supra note 101.

${ }^{141}$ Almost any important governmental actor or institution can be in a position to undermine the rule of law in any of multiple respects through any of various sorts of acts. Determining proper levels of subsidization, in proper forms, in the proper contexts, and then properly administering such subsidization would seem plainly unmanageable, and itself an inviting opportunity to further jeopardize the rule of law.

142 See supra Part IV.

${ }^{143}$ LeARNed HAND, The SpIRIT OF Liberty 189-190 (Irving Dillard ed., 3d ed., 1960). For a contrasting tone and emphasis, while assuming the importance of the rule of law, see the classic lines attributed to Thomas More: 
Transposed to the rule of law context, Judge Hand's observation supports our argument that the rule of law is indispensable, but is only more or less infrequently a genuinely high priority of all of the contemporary legal actors, and for the reasons discussed above, is chronically undersupplied. What Learned Hand says of liberty might thus in a serious sense be said of the rule of law.

To further pursue Learned Hand's metaphor, if the rule of law is to lie in the hearts of men and women, and to thus be secure, more than institutional reforms are required. The rule of law, simply put, is neither self-sustaining nor sustainable merely by some combination of legal or economic mechanisms. ${ }^{144}$ Something else is inevitably needed as well.

If the rule of law is to be sustained closer to a generally desired level, we must better appreciate that the values of the game-theoretic choices and the payoffs and outcomes made by and available to legal actors are not independent of their own alterable preferences and priorities. Our valuations of distinctly partisan, ideological, or institutional payoffs, and our willingness to incur collective rule of law costs in pursuing such payoffs, can change over time. Such valuations reflect in part what we might call our stock of civic $^{145}$ or personal ${ }^{146}$ virtues. And our stock of civic and relevant personal virtues is alterable, however impermanently, ${ }^{147}$ over time through processes of education ${ }^{148}$ as it is broadly understood.

And when the last law was down, and the Devil turned round on you-where would you hide, Roper, the laws all being flat? . . . This country's planted thick with laws . . . and if you cut them down ... d'you really think you could stand upright in the winds that would blow then?

Robert Bolt, A Man for All Seasons: A Play in Two Acts 66 (2d ed., 1962).

${ }^{144}$ The usual array of mechanisms for addressing the problems of undersupplied public goods and negative externalities begins with subsidies. See supra note 141 and accompanying text. Various sorts of programs focusing on pricing schemes, compensation payments, marketable permits, regulations, and taxing schemes are also sometimes available. No combination of such mechanisms, in our context, seems either feasible or sufficient. See e.g., Negative Externalities, ECON. ONLINE, http://www.economicsonline.co.uk/Market_failures/Externalities.html (last visited Sept. 25, 2015); Cowen, supra note 91; see also OSTROM, supra note 108, at 10-11; STEPHEN BREYER, REGULATION AND ITS REFORM, 62-63, 70 (Harvard Univ. Press 1982).

${ }^{145}$ See, e.g., Richard Dagger, CiviC Virtues: Rights, Citizenship, AND Republican LiBerALISM 6-7 (1997); Frank Michelman, Law's Republic, 97 YALE L.J. 1493, 1515 (1988); Cass R. Sunstein, Beyond the Republican Revival, 97 YALE L.J. 1539, 1550-51 (1988); see also HERBERT R. Storing, What the Anti-Federalists Were For: The Political Thought of the Opponents of THE CONSTITUTION 20-21 (1981).

146 See generally Christopher Peterson \& MARTin SEligman, Character Strengths AND VIRTUES: A HANDBOOK AND CLASSIFICATION (2004) (identifying various virtues and analyzing the impact these virtues have on personal and social lives).

${ }^{147}$ See Hardin, The Tragedy of the Commons, supra note 108, at 1245 ("The inexorable succession of generations" requires such education to be "constantly refreshed.").

${ }^{148}$ See id. ("Education can counteract the natural tendency to do the wrong thing" even in public 
What, then, are the civic and personal virtues that might distinctively bear upon our ignorance of, or our degree of genuine concern for, risks to the rule of law? ${ }^{149}$ We might start by analogy with the virtues that tend to lead us individually to not pollute the local air and water, even if we would likely not be punished for contributing to such a public bad, and even if it would be cheaper and more convenient for us as individuals to pollute than to refrain from doing so. The classic discussion of some of the relevant virtues is found, not surprisingly, in Aristotle. ${ }^{150}$ An illustrative list of such relevant virtues could include reasonable and appropriate humility, ${ }^{151}$ reasonable self-restraint or temperance, ${ }^{152}$ awareness of one's limitations, ${ }^{153}$ prudence and practical wisdom, ${ }^{154}$ and freedom from the classic vice known as hubris. ${ }^{155}$

The emphasis on these particular virtues flows partly from the sense that, as in the case of littering, our impulse to self-indulgence must be overcome. But more important in the rule of law context is the need for virtues that limit personal or institutional arrogance. In this sense, arrogance may manifest itself as any form of under-weighing, given one's own actual limitations and the apparently reasonable views of a number of other institutional actors.

Perhaps the best-known and most extreme American case of official conscious and direct disdain for the rule of law is that of the Watergate

good or public bad contexts.); see also infra note 161 and accompanying text.

${ }^{149}$ It is also possible that one or more virtues might lead us to revise upward our valuation of the rule of law in itself, but we need not press this point.

${ }^{150}$ See Aristotle, The Nicomachean Ethics bk. VII (Hugh Tredennick ed., J.A.K. Thomson trans., Penguin Classics, 2004) (350 BCE) (discussing what we might call reasonable self-restraint, selfcontrol, self-discipline, a spirit of moderation, temperance, continence, and a sense of one's fallibility and limits, etc., as distinguished from opposing vices, including, ultimately, pride or lack of appropriate humility). In areas of causal or other technical complexity, matters will commonly be sufficiently complex to allow us to rationalize self-serving or emotionally gratifying if misguided analyses. See Manzi, supra note 102. However, virtues such as appropriate humility may pose an obstacle to such behavior. See, e.g., NANCY SHERMAn, THE FABRIC OF CHARACTER: ARISTOTLE'S THEORY OF ViRTUE ch. 3, 55 (1989). For a brief discussion of Plato's treatment of temperance, see TERENCE IRWIN, PlATO's ETHICS 40-42 (1995).

${ }^{151}$ See, e.g., James Kellenberger, Humility, 47 AM. PHIL. Q. 321, 323 (2010); Peterson \& SELIGMAN, supra note 146, ch. 20.

${ }^{152}$ See, e.g., Helen F. North, The Concept of Sophrosyne in Greek Literacy Criticism, 43 ClaSSICAL Philology 1, 2 (1948); Peterson \& Seligman, supra note 146, ch. 22.

${ }^{153}$ See, e.g., Helen F. North, A Period of Opposition to Sôphrosynê in Greek Thought, 78 Transactions \& Proc. AM. Philological Ass'N 1, 2 (1947) [hereinafter North, Opposition]; PETERSON \& SELIGMAN, supra note 146, ch. 20.

${ }^{154}$ See id.; ReEve, Aristotle, On Practical Wisdom, supra note 36; C.D.C. ReEve, ACtion, Contemplation, AND Happiness: An Essay on ARistotle ch. 5 (2012); Peterson \& Seligman, supra note 146, ch. 21.

${ }^{155}$ See North, Opposition, supra note 153, at 2; PETERSON \& SEligMAN, supra note 146, ch. 20. 
break-in, the ensuing cover-up, ${ }^{156}$ and related litigation. ${ }^{157}$ The Watergate episode involved, it is fair to say, a presidential attempt to advance some personal, partisan, or ideological agenda, at a potentially substantial, if murky, cost to the rule of law. ${ }^{158}$ These presidential efforts ran contrary to the implicit or explicit judgment of any number of representatives of coequal branches, a number of whom presumably shared many of the President's partisan identifications and general political goals. ${ }^{159}$ Such a presidential course of conduct, in that context, clearly reflects, among other vices, that of potentially remediable, if in this case extreme, civic and personal arrogance. ${ }^{160}$

More broadly, despite, or because of, any modern educational emphases on career preparation, workplace technologies, credentialization, technical knowledge, marketability, skill acquisition, and the signaling of statuses and competencies, there is room within formal educational structures for uncoercively cultivating a number of the basic virtues relevant to sustaining the rule of law. ${ }^{161}$

156 See generally CARl Bernstein \& Bob Woodward, All the President's Men (Simon \& Schuster 2014) (1976) (chronicling the Watergate break-in and cover-up, and depicting the roles of each major player associated with the scandal).

${ }^{157}$ See, e.g., United States v. McCord, 509 F.2d 334, 339 (D.C. Cir. 1974) (en banc) (affirming conviction); United States v. Liddy, 509 F.2d 428, 431-32 (D.C. Cir. 1974) (affirming conviction); Mitchell v. Sirica, 502 F.2d 375, 376 (D.C. Cir. 1974) (per curium) (denying petition for writ of mandamus for Judge Sircla's recusal); see also Anthony J. Gaughan, Watergate, Judge Sirica, and the Rule of Law, 42 MCGEORGE L. REV. 343, 344-46 (2011) (discussing rule of law complications and ambiguities associated with the trials of non-Presidential actors involved in Watergate).

${ }^{158}$ Gaughan, supra note 157, at 349-50.

159 See generally BoB WoOdWARD \& CARL Bernstein, The FinAl DAYs (reissue ed., 2005) (discussing the roles of the major players in the Watergate scandal); WATERGATE.INFO, Judiciary Committee Impeachment Hearings, WATERGATE: THE SCANDAL THAT BROUGHT Down RichaRD NIXON, http://watergate.info/impeachment/judiciary-committee-hearings (last visited Sept. 27, 2015) (consisting of a collection of the documents submitted to the 1974 House of Representatives Judicary Committee relating to the Watergate investigation).

${ }^{160}$ See William Shakespeare, King LEAR act IV, sc. VI (discussing the vice of personal arrogance); Cultivating Virtues: Perspectives From Philosophy, TheOlOGY, AND Psychology (Nancy E. Snow ed., 2014) (providing a more elaborate discussion from multiple authors' perspectives on inculcating virtue).

${ }^{161}$ For some classical background, see, for example, MARK LUTZ, SOCRATES' EdUCATION tO VIRTUE: LEARNING THE LOVE OF THE NOBLE 182 (1998) ("Socratic education offers evidence that our love of noble virtue is not simply the product of arbitrary historical movements and concealed wills to power . . .."); Plutarch, Can Virtue Be Taught?, in Plutarch's Moralia vol. VI, at 5-13 (T.E. Page et al. eds., W.C. Helmbold trans., Loeb Classical Library 1939) (100 AD). For collections of references to modern intervention efforts aimed at encouraging at least one of the basic classic virtues, see PETERSON \& SELIGMAN, supra note 146, at 194-95, 385-86, 424-26, 472-74. For contemporary references to education, broadly defined, in the basic virtues, see, for example, ROBERT MERRIHEW ADAMS, A THEORY OF VIRTUE ch. 12, at 212-32 (2006) (discussing LAWRENCE KOHLBERG, ESSAYS ON MORAL DEVELOPMENT vol. 2, at 548-552 (1984) and RAWLS, supra note 33, at 463-66, 470, 474, 49091), VAlerie Tiberius, Moral PSychology: A CONTEMPORARy InTroduction 122 (2015) 


\section{CONCLUSION}

The institution of the rule of law is in some respects akin to material civic infrastructure. Maintaining the rule of law involves deep problems roughly parallel to those we often observe in the context of material infrastructure maintenance. ${ }^{162}$ Maintaining a local sewer system, for example, is no more likely to inspire fervent support and major campaign donations than is an appropriate prioritizing of the rule of law. Damage to the rule of law will commonly not be conspicuous, immediate, or causally clear. After all, a culture that inspires systematic deprioritizing of the rule of law likely has other attributes upon which any undesired outcomes can be blamed. Nevertheless, we ought to recognize the nature, scope, and severity of our most difficult rule of law problems. And we ought to recognize and address such problems not solely with legal and political machinations, but with sensible attention to the relevant virtues.

\footnotetext{
(discussing the cultivation of habits conducive to improved deliberation), and Randall Curren, Judgment and the Aims of Education, 31 SOC. PHIL. \& POL'Y 36, 37 (2014) (noting that sound judgment or practical wisdom is "an important, culminating aim of education" as "it is in the nature of education to guide students in acquiring . . . virtues foundational to living well"). See also Dan P. McAdams, Psychological Science and the Nicomachean Ethics: Virtuous Actors, Agents, and Authors, in Cultivating ViRTUeS, supra note 160, at 307; Darcia Narvaez, The Co-Construction of Virtue: Epigenetics, Development, and Culture, in Cultivating ViRTUES, supra note 160, at 251; Ross A. Thompson, The Development of Virtue: A Perspective from Developmental Psychology, in Cultivating ViRTUES, supra note 160, at 297 ("[S]ignificant aspects of moral character and virtue develop with [post-early childhood] growth in personality, self-regulation, cognitive complexity, selfawareness, and relational experience."). For references to virtue cultivation in the legal context, see, for example, William A. Galston, Liberal Purposes: Goods, Virtues, and Diversity in the LIBERAL STATE 244 (1991) ("Recent interpretations of the liberal-theoretical tradition have emphasized the copresence of institutional and character-based arguments, as have rereadings of the Federalist.") (emphasis in original), and Amy Gutmann, Can Virtue Be Taught to Lawyers?, 45 STAN. L. REV. 1759, 1770 (1993) (emphasizing development of the capacity for sound and informed deliberation, along with the traditional themes of attorney "character" and the presumably virtuous pursuit of social justice).

${ }^{162}$ See, e.g., America's Crumbling Infrastructure and How to Fix It: Hearing Before the J. Econ. Comm., 113th Cong. 26-29 (2013).
} 
